\title{
Conditions for hydrolysis of perilla seed meal protein for producing hydrolysates and ultrafiltered peptides and their antioxidant activity
}

\author{
Bo Yeon Park, Kyung Young Yoon* \\ Department of Food and Nutrition, Yeungnam University, Gyeongsan 38541, Korea
}

\section{들깨박단백질로부터 가수분해물과 한외여과 펩타이드 생산을 위한 효소가수분해 조건 및 항산화 활성}

\author{
박보연 · 윤경영* \\ 영남대학교 식품영양학과
}

\begin{abstract}
This study was conducted to investigate the antioxidant activity of perilla seed meal (PSM) protein hydrolysates and peptide fractions prepared using proteolytic enzymes and ultrafiltration to improve the usability of PSM as a functional food ingredient. Optimal conditions for producing PSM protein hydrolysate using Flavourzyme were determined to be $\mathrm{pH} 7.0$, temperature $50^{\circ} \mathrm{C}, 10$ unit of enzyme concentration, and $4 \mathrm{~h}$ hydrolysis time. The yield of each peptide fraction obtained by ultrafiltration was found to be the highest $(45.65 \%)$ in the $<1 \mathrm{kDa}$ fraction, followed by 5-10 kDa (16.45\%), >10 kDa (16.37\%), 1-3 kDa (10.86\%), and 3-5 kDa (10.67\%), respectively. The DPPH radical scavenging activity was the highest in the hydrolysate, the reducing power was the highest in the 3-5 kDa fraction, and the superoxide dismutase-like activity was the highest in the <1 kDa fractions. The hydrolysate and peptide fractions produced from PSM protein showed different antioxidant activities, and thus they could potentially be used as functional food ingredients. Further evaluation as a functional food ingredient would allow the application of PSM protein hydrolysates as food materials.
\end{abstract}

Key words : perilla seed meal, agricultural by-products, ultrafiltered peptides, enzymatic hydrolysis, antioxidant activity

\section{서 론}

펩타이드는 단백질이 아미노산으로 분해되는 과정의 중 간산물로, 다양한 조합의 아미노산이 아미노기와 카르복실 기와의 탈수축합반응에 의해 중합물을 형성하고 있는 것으 로 일반적으로 분자량 10,000 dalton 이하의 것을 말한다(1). 이 중 인체의 건강에 영향을 주는 펩타이드를 총칭해서 생리활성 펩타이드로 정의한다(2). 식품 중에 존재하는 생 리활성 펩타이드는 동물성 식품유래의 호르몬류나 식물성

*Corresponding author. E-mail : yoonky2441@ynu.ac.kr Phone : 82-53-810-2878, Fax : 82-53-810-4666

Received 19 July 2018; Revised 6 August 2018; Accepted 8 August 2018.

Copyright (c) The Korean Society of Food Preservation. All rights reserved.
식품유래의 효소저해물질과 소화과정이나 식품 가공과정 중에 부분 가수분해 되어 생성된다. 펩타이드는 항산화 활 성을 비롯하여 항당뇨, 항고혈압, 항암, 피부미백 및 피부면 역 활성, 항고혈압, 콜레스테롤 조절 작용 및 혈소판 응집 저해활성 등의 생리활성이 있어 관심이 높아지고 있다 (3-6). 뿐만 아니라 펩타이드는 용해성, 점도, 향미, 기포성 및 유화성과 같은 기능적 특성을 가지고 있어(7), 소화·흡수 가 용이할 뿐만 아니라 다양한 식품 및 가공품에서의 이용 성이 높다(8)

들깨(Perilla frutescens var. japonica HARA)는 꿀풀과에 속하는 일년초의 종실로서 우리나라를 비롯한 중국, 일본 등지에서 재배되고 있으며, 각지의 산기슭이나 길가의 습 지에서 흔하게 자라므로 현재 전국적으로 재배되고 있고 그 수요가 증가함에 따라 재배 면적이 증가되고 있다(9). 들깨는 잎을 식용하고 종자를 생이나 볶아 여러 가지 음식 
을 만드는데 사용되며, 볶은 들깨종자에서 기름을 착유하 거나 가루를 내어 양념으로 쓰기도 한다. 2010년 국민건강 영양조사에 따르면 들깨는 다가불포화지방산, $\omega-3$ 계 지방 산, 칼슘 및 조섬유 섭취량 주요 급원식품 상위권으로 보고 되어(10), 들깨가 한국인의 식생활 및 식습관에 많은 영향을 차지하는 식품임을 알 수 있다. 또한 들깨종실에는 우리 몸에 필요한 필수영양소가 골고루 함유되어 있으며, 특히 지질의 함량이 매우 높다(11). 들깨 지질은 $\omega-3$ 계 고도불포 화지방산의 일종인 a-linolenic acid의 성분이 많으며, $a$ -linolenic acid는 혈압저하, 혈전증 개선, 암세포 증식 억제 등의 기능성을 가지고 있다(12). 들깨는 지방질 이외에도 다양한 생리활성성분이 존재하고 있는데, Park 등(13)은 들깨의 식이섬유소에서 항돌연변이 효과가 있음을 보고하 였다. 들깨 종자에는 기름이 약 $40 \%$ 함유되어 있어 주로 기름을 착유하여 이용하는데, 들깨 종자를 착유하고 남은 부산물인 들깨박의 주성분은 단백질이며 이외에도 인체에 유효한 성분을 다량 함유하고 있어 이용가치가 큰 농산부산 물이다. 지금까지 식품의 단백질로부터 다양한 생리활성 펩타이드가 생산되어 기능성 식품소재로서 이용 가능성이 제시되어 왔다. 그러나 들깨박 연구는 들깨박에서 분리한 페놀화합물의 항산화 효과에 대한 연구가 대부분이며 $(11,14)$, 들깨박단백질의 생리활성 특성에 관한 연구가 미 비하다.

따라서 본 연구에서는 농산가공부산물인 들깨박의 기능 성 식품소재로써의 활용가능성을 확인하기 위한 연구의 일환으로 단백질분해효소를 이용하여 들깨박단백질로부 터 효소가수분해물 및 한외여과 펩타이드를 분획하고자 하였다. 이를 위해 다양한 단백질가수분해효소를 이용하여 들깨박단백질 분해를 위한 최적의 효소를 선정하고, 선정 된 효소의 최적 분해조건을 찾고자 하였다. 또한 들깨박단 백질 효소가수분해물 및 한외여과 펩타이드 분획의 항산화 활성을 측정하여 건강기능성 식품소재를 비롯한 다양한 식품재료로의 활용을 위한 기초자료를 제공하고자 하였다.

\section{재료 및 방법}

\section{실험재료}

본 실험에 사용된 들깨(Perilla frutescens var. japonica HARA)박은 전라남도 해남군 화산면에서 재배된 국내산 들깨를 냉압착 방식으로 착유하고 남은 부산물로 Queensbucket(Seoul, Korea)으로부터 제공받았다. 들깨박 은 이물질을 제거하고 마쇄한 후 체질하여 $-40^{\circ} \mathrm{C}$ deep freezer(MDF, Sanyo, Tokyo, Japan)에 보관하면서 실험에 사용하였다. 들깨박 단백질을 가수분해하기 위하여 사용한 단백질가수분해 효소인 pepsin, trypsin 및 papain은 SigmaAldrich Co.(St. Louis, MO, USA)에서 구입하였으며, acalase, protamex, neutrase 및 flavourzyme은 Novo사 (Nordisk Co., Bagvaerd, Denmark) 제품을 사용하였다.

\section{들깨박단백질 추출}

들깨박으로부터 단백질을 추출하기 위해서 동결건조된 들깨박의 중량 대비 $1: 10(\mathrm{w} / \mathrm{v})$ 의 증류수를 넣어 $25^{\circ} \mathrm{C}, 120$ rpm의 shaking water bath(BS-11, JeioTech, Seoul, Korea)에 서 60 분간 교반하였다. 이 후 $1 \mathrm{~N} \mathrm{NaOH}$ 를 적정량 주입하여 $\mathrm{pH} \mathrm{10.0으로} \mathrm{일정하게} \mathrm{유지시켜} 25^{\circ} \mathrm{C}$ 에서 60 분간 단백질을 용출시킨 후, 원심분리(Supra-21K, Hanil, Incheon, Korea)하 여 상등액을 취하였다. 상등액에 $1 \mathrm{~N} \mathrm{HCl}$ 용액을 이용하여 $\mathrm{pH} 4.0$ 로 조정하고 $25^{\circ} \mathrm{C}$ 에서 30 분 동안 반응시켜 단백질을 침전시킨 후, $10,000 \mathrm{rpm}$ 에서 30 분간 원심분리하여 침전 단백질을 얻었다. 이때 얻어진 단백질 침전물을 중량대비 $1: 2(\mathrm{w} / \mathrm{v})$ 의 증류수를 가하여 homogenizer(AM-1, Nissei, Tokyo, Japan)로 충분히 균질화시킨 후 $0.1 \mathrm{~N} \mathrm{NaOH}$ 을 이용 하여 $\mathrm{pH}$ 7.0로 중화시킨 다음, 동결건조 시켜 효소가수분해 물 제조를 위한 시료로 사용하였다.

\section{효소활성 측정}

효소활성 측정은 Anson(15)의 방법을 변형하여 측정하 였다. 즉, 시험관에 buffer solution $1 \mathrm{~mL}$ 를 가한 다음, 기질용 액 $(0.6 \%$ casein, $\mathrm{pH} 7.0) 2.5 \mathrm{~mL}$ 을 넣고 $37^{\circ} \mathrm{C}$ 로 incubation한 후 효소액 $0.5 \mathrm{~mL}$ 넣고 $37^{\circ} \mathrm{C}$ 에서 10 분간 반응시켰다. 반응 후 $0.44 \mathrm{M}$ trichloroacetic acid(TCA) $2.5 \mathrm{~mL}$ 를 넣어 반응을 중지시키고 실온에서 10 분간 방치한 다음 원심분리하였다. 이 후 상등액 $1 \mathrm{~mL}$ 에 $0.55 \mathrm{M} \mathrm{NaCO}_{3}$ 용액 $5 \mathrm{~mL}$ 와 $1 \mathrm{~N}$ Folin \& Ciocalteus reagent $1 \mathrm{~mL}$ 용액을 넣어 $37^{\circ} \mathrm{C}$ 에서 30 분 간 발색시켜 $660 \mathrm{~nm}$ 에서 흡광도(U-2900, Hitachi)를 측정하 였다. 효소활성 단위는 $\mathrm{pH} 7.0,37^{\circ} \mathrm{C}$ 에서 casein(SigmaAldrich Co.)으로부터 1분 동안 $1 \mu \mathrm{mol}$ 의 tryrosine을 유리시 키는 효소의 양을 1 unit으로 하였다. 위의 방법에 따라 측정된 단백질가수분해효소의 활성은 pepsin 81.14 unit $/ \mathrm{mL}$, trypsin 314.51 unit/mL, papain 259.82 unit $/ \mathrm{mL}$, acalase 420.37 unit $/ \mathrm{mL}$, protamex $498.60 \mathrm{unit} / \mathrm{mL}$, neutrase $562.69 \mathrm{unit} / \mathrm{mL}$ 및 flavourzyme $189.65 \mathrm{unit} / \mathrm{mL}$ 이었다.

\section{들깨박단백질 가수분해를 위한 효소 선정}

들깨박단백질의 가수분해를 위한 최적 효소를 선정하기 위하여 Xie 등(16)의 방법을 약간 변형하여 Table 1 의 효소 최적 조건에 따라 효소 반응하였다. 즉, 들깨박단백질은 각 효소의 최적 buffer solution를 이용하여 1:20(w/v) 농도로 제조하였으며, 10 unit의 효소를 첨가하였다. 그 후 shaking incubator(BS-11, JeioTech)를 이용하여 각 효소의 최적 온도 에서 일정한 시간 동안 교반한 후, $99^{\circ} \mathrm{C}$ 에서 5 분간 가열하여 효소 반응을 정지시킨 후 $18,000 \times g$ 에서 20 분 동안 원심분 리하여 얻어진 상등액의 가수분해도 측정하였다. 
Table 1. Hydrolysis conditions of proteolytic enzymes for perilla seed meal protein hydrolysis

\begin{tabular}{cccc}
\hline \multirow{2}{*}{ Proteases } & \multicolumn{3}{c}{ Hydrolysis conditions } \\
\cline { 2 - 4 } & Temperature $\left({ }^{\circ} \mathrm{C}\right)$ & $\mathrm{pH}$ & Buffer solution \\
\hline Pepsin & 37 & 2 & $0.1 \mathrm{M}$ glycine-HCl buffer \\
Trypsin & 37 & 8 & $0.1 \mathrm{M}$ sodium phosphate buffer \\
Papain & 37 & 6 & $0.1 \mathrm{M}$ sodium phosphate buffer \\
Acalase & 50 & 7 & $0.1 \mathrm{M}$ sodium phosphate buffer \\
Protamex & 50 & 7 & $0.1 \mathrm{M}$ sodium phosphate buffer \\
Neutrase & 50 & 7 & $0.1 \mathrm{M}$ sodium phosphate buffer \\
Flavourzyme & 50 & 7 & $0.1 \mathrm{M}$ sodium phosphate buffer \\
\hline
\end{tabular}

\section{가수분해도 측정}

단백질가수분해물의 가수분해도는 가수분해물에 $20 \%$ $\mathrm{TCA}$ 를 동량 첨가하여 실온에서 30 분 동안 방치시키고 원 심분리한 다음 상등액을 일정량 취하여, bicinchoninic $\operatorname{acid}(\mathrm{BCA})$ 법(17)에 준하여 $10 \% \mathrm{TCA}$ 가용성 단백질량을 측정한 후, 아래의 식을 이용하여 산출하였다.

$$
\text { 가수분해물 }(\%)=\frac{10 \% \mathrm{TCA} \text { 가용성 단백질량 }}{\text { 총 단백질량 }} \times 100
$$

들깨박단백질 가수분해물 및 한외여과 펩타이드 분획 제조 들깨박단백질의 가수분해물을 제조하기 위하여 Xie 등 (16)의 방법을 약간 변형하여 효소 최적 추출조건에 따라 가수분해하였다. 0.1 M sodium phosphate buffer( $\mathrm{pH}$ 7.0)를 이용하여 $5 \%(\mathrm{w} / \mathrm{v})$ 농도로 제조된 들깨박단백질 용액 25 $\mathrm{mL}$ 에 flavourzyme 10 unit를 첨가하여 $50^{\circ} \mathrm{C}$ 에서 4 시간 동안 효소 반응시켰다. 이후 $99^{\circ} \mathrm{C}$ 에서 10 분간 가열하여 효소 반 응을 정지시킨 후 $18,000 \times g$ 에서 20 분 동안 원심분리하였 다. 얻어진 상등액을 한외여과막(molecular weight cut-off $1,3,5,10 \mathrm{kDa}$ )을 사용하여 분자량 $<1 \mathrm{kDa}, 1-3 \mathrm{kDa}, 3-5$ $\mathrm{kDa}, 5-10 \mathrm{kDa},>10 \mathrm{kDa}$ 으로 분획하고 동결건조하여 각각 의 수율 및 항산화 활성을 측정하였다.

\section{한외여과 분획물의 수율 측정}

한외여과에 의해 얻은 각 분획물의 수율은 동결건조한 후 중량법 따라 백분율로 표시하였으며, 다음과 같이 계산 하였다.

$$
\text { 수율 }(\%)=\frac{\text { 각 분획물의 건조 중량 }(\mathrm{g})}{\text { 들깨박단백질 가수분해물의 중량 }(\mathrm{g})} \times 100
$$

\section{항산화 활성}

1,1-Diphenyl-2-picryl hydrazyl(DPPH) 라디칼 소거능은
Jang 등(18)의 방법에 준하여 측정하였다. Microwell plate에 농도별로 제조한 각 들깨박단백질 가수분해물 $100 \mu \mathrm{L}$ 를 취한 후 $0.2 \mathrm{mM} \mathrm{DPPH}$ 용액 $200 \mu \mathrm{L}$ 를 가하고, $37^{\circ} \mathrm{C}$ 에서 30 분간 incubation 후 microplate reader(EPOCH, BioTek Instrument Inc, Winooski, VT, USA)를 이용하여 $517 \mathrm{~nm}$ 에 서 흡광도를 측정하였다.

환원력은 $\mathrm{Mau}$ 등(19)의 방법에 따라 측정하였다. e-Tube 에 농도별로 제조한 시료 $250 \mu \mathrm{L}, 0.2 \mathrm{M}$ sodium phosphate buffer(pH 6.6) $250 \mu \mathrm{L}$ 와 $1 \%$ potassium ferricyanide $\left(\mathrm{KFe}(\mathrm{CN})_{6}\right)$ $250 \mu \mathrm{L}$ 을 첨가하여 잘 혼합하고 $50^{\circ} \mathrm{C}$ 에서 20 분간 반응시켰 다. 이 반응액에 $10 \%$ trichloroacetic $\operatorname{acid}\left(\mathrm{CCl}_{3} \mathrm{COOH}\right) 250$ $\mu \mathrm{L}$ 를 첨가한 후 $25^{\circ} \mathrm{C}, 1,000 \mathrm{rpm}$ 에서 10 분 동안 원심분리하 였다. 이 상등액 $250 \mu \mathrm{L}$ 와 $0.1 \%$ ferric chloride $\left(\mathrm{FeCl}_{3} \cdot 6 \mathrm{H}_{2} \mathrm{O}\right)$ $50 \mu \mathrm{L}$ 를 반응시켜 microplate reader $(\mathrm{EPOCH}$, BioTek Instrument Inc.)를 이용하여 $700 \mathrm{~nm}$ 에서 흡광도를 측정하 였다.

Superoxide dismutase(SOD) 유사활성 측정 은 Bradford(20) 의 방법에 따라 농도별로 제조한 시료 $0.5 \mathrm{~mL}$ 에 $\mathrm{pH} 8.5$ 로 보정한 Tris- $\mathrm{HCl}$ buffer(50mM tris[hydroxymethyl] aminomethane+10 mM EDTA) $3 \mathrm{~mL}$ 와 $7.2 \mathrm{mM}$ pylogallol $0.2 \mathrm{~mL}$ 를 가하여 $25^{\circ} \mathrm{C}$ 에서 10 분간 방치한 후 $1 \mathrm{~N} \mathrm{HCl} 0.1 \mathrm{~mL}$ 로 반응을 정지시킨 후 spectrophotometer(U-2900, Hitachi)을 이용하여 $420 \mathrm{~nm}$ 에서 흡광도를 측정하였다.

\section{통계처리}

본 실험의 결과는 3 반복으로 수행되었으며, 각 실험 결과 에 대한 평균값과 표준편차를 나타내었다. 통계분석은 SPSS(Ver. 21, Chicago, IL, USA) 통계프로그램을 이용하여 일원배치 분산분석법을 $\mathrm{p}<0.05$ 수준에서 실시하였으며, 실 험의 평균치간의 유의적 차이는 Duncan's multiple range test로 검증하였다. 또한 가수분해물의 효소반응시간에 따 른 가수분해율의 유의차를 $\mathrm{p}<0.05$ 수준에서 $\mathrm{t}$-test로 검증하 였다.

\section{결과 및 고찰}

\section{들깨박단백질 가수분해를 위한 효소 선정}

들깨박단백질로부터의 가수분해물을 생산하기 위한 효 소를 선정하기 위해 7종의 단백질분해효소를 이용하여 효 소 반응시킨 후 이들의 가수분해도를 측정한 결과는 Fig. 1 과 같다. 각 효소 종류에 따른 들깨박단백질의 가수분해도 는 2시간일 때는 flavourzyme $66.60 \%$, protamex $55.57 \%$, papain $53.49 \%$, pepsin $49.91 \%$, trypsin $49.87 \%$, acalase $47.97 \%$, neutrase $42.60 \%$ 로 나타났다. 4시간의 경우는 flavourzyme $70.68 \%$, protamex $56.43 \%$, papain $56.08 \%$, trypsin $55.75 \%$, acalase $52.37 \%$, pepsin $51.04 \%$, neutrase 
$43.89 \%$ 의 가수분해도가 나타나, 2 시간 반응에 비해 유의적 으로 높은 가수분해도를 나타내었다. 들깨박단백질 가수분 해도는 단백질분해효소 중에서 flavourzyme이 가장 높았는 데, Yoon 등(21)은 flavourzyme은 exo형과 endo형을 동시에 가수분해할 수 있는 단백질분해효소이기 때문인 것으로 추정하였다. 또한, 2 시간 반응의 경우 가수분해도는 flavourzyme 다음으로 protamex, papain, trypsin, pepsin 순으 로 높게 나타났다. 이 중 protamex의 경우는 2 시간 반응에서 가수분해도는 $55.57 \%$ 로 flavourzyme 다음으로 높았지만, 4시간 반응에서는 $56.43 \%$ 에 불과하여 다른 효소에 비해 반응시간 증가에 따른 가수분해도의 증가가 상대적으로 낮았다. 이는 같은 기질에서도 효소 종류에 따라 가수분해 도 차이가 있으며 단백질의 구조적인 민감성과 효소의 특이 기질에 대한 반응성의 차에 기인한 것으로 판단된다(22). 또한, 반응시간에 따른 유의적인 차이는 나타났지만 반응 시간이 길어짐에 따라 가수분해도가 완만하게 증가하였는 데, $\operatorname{Kim}(22)$ 은 효소 첨가 시 반응초기에는 반응성이 좋은 펩타이드 결합이 우선적으로 분해되고, 반응성이 약한 펩 타이드 결합은 천천히 분해되기 때문으로 보고하였다. 또 한 일정 반응 후에 일정한 분해도를 유지하는 것은 가수분 해 생성물이 가수분해 속도를 저해하기 때문으로 보고하였 다. 이상의 결과에서 들깨박단백질 가수분해물 제조를 위 한 효소는 가수분해도가 가장 높은 flavourzyme으로 선정 하였다.

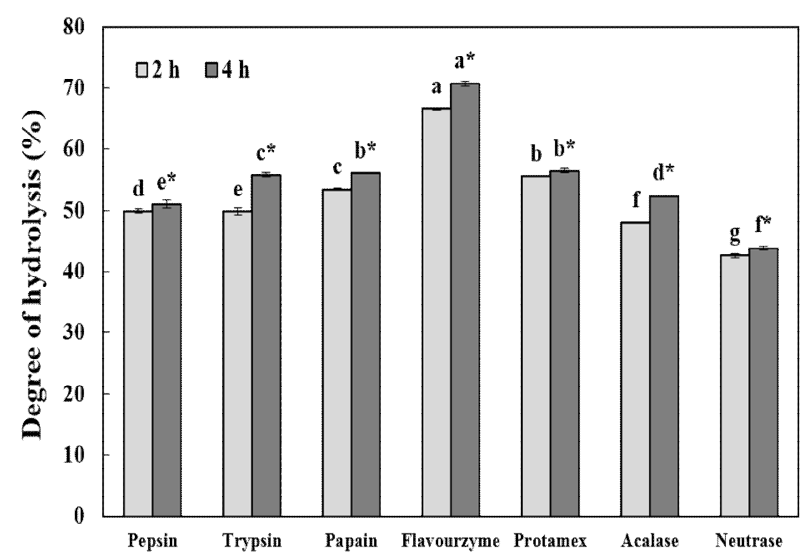

Fig. 1. Degree of hydrolysis of enzymatic hydrolysates from perilla seed meal protein.

The bar represents the mean and SD $(n=3)$.

Values with different letters in the same hydrolysis time are significantly different at $\mathrm{p}<0.05$.

Significant difference between $2 \mathrm{~h}$ and $4 \mathrm{~h}$ by the Student's t-test $(\mathrm{p}<0.05)$

\section{Flavourzyme을 이용한 들깨박단백질 가수분해물의 최 적 분해조건}

들깨박단백질 효소가수분해물 생산을 위한 최적 분해조 건을 설정하기 위하여 $\mathrm{pH}$, 온도, 효소농도에 따른 가수분해
물의 가수분해도를 측정하였으며, 그 결과를 Table 2에 나 타내었다. 가수분해물의 가수분해도는 $\mathrm{pH} 7.0$ 에서 $70.50 \%$ 으로 유의적으로 가장 높았으며 $(\mathrm{p}<0.05), \mathrm{pH} 4.0$ 에서 $\mathrm{pH}$ 7.0 까지는 가수분해도가 유의적으로 증가하였다. 그 이후 에는 가수분해도가 감소하여 $\mathrm{pH} 9.0$ 에서는 $28.29 \%$ 로 가장 낮은 가수분해도를 보였다. Beak 등(23)의 연구에서는 홍게 자숙부산물의 가수분해물이 $\mathrm{pH}$ 7.45에서 가수분해도가 가 장 높아 본 연구 결과와 유사하였다. 따라서 들깨박단백질 로부터 가수분해물 생산을 위한 flavourzyme의 최적 $\mathrm{pH}$ 는 7.0 으로 선정하였다. 최적 $\mathrm{pH} 7.0$ 에서 온도에 따른 가수분 해물의 가수분해도를 측정한 결과, $50^{\circ} \mathrm{C}$ 에서 $69.31 \%$ 로 유 의적으로 가장 높았으며 $(\mathrm{p}<0.05), 30^{\circ} \mathrm{C}$ 에서 $59.11 \%$ 으로 가 장 낮은 값을 나타내었다. Jang 등(24)의 연구에서는 홍게 가공부산물로부터 단백질 가수분해물을 얻기 위해 flavourzyme을 이용하여 가수분해도를 측정한 결과, $50^{\circ} \mathrm{C}$ 에서 가장 높은 분해도를 나타내 본 연구 결과와 일치하였 다. 따라서, 들깨박단백질로부터 가수분해물 생산을 위한 flavourzyme의 최적 온도는 $50^{\circ} \mathrm{C}$ 로 결정하였다. 최적 $\mathrm{pH}$ $7.0,50^{\circ} \mathrm{C}$ 에서 효소농도에 따른 가수분해물의 가수분해도 를 측정한 결과, 5 unit에서 $44.78 \%$ 으로 유의적으로 가장 낮았으며, 10 unit에서 $67.68 \%$ 로 유의적으로 가장 높게 나 타났다(p<0.05). 그 후에는 가수분해도가 감소하였는데, 이 는 효소가 반응할 수 있는 기질의 양이 부족하기 때문으로 사료된다. 따라서 들깨박단백질로부터 가수분해물 생산을 위한 flavourzyme의 최적 효소농도는 10 unit으로 결정하였 
Table 2. Degree of hydrolysis of perilla seed meal protein hydrolysate obtained by flavourzyme at different $\mathrm{pH}$, temperature and enzyme concentration

\begin{tabular}{|c|c|c|}
\hline \multicolumn{2}{|c|}{ Hydrolysis conditions } & \multirow{2}{*}{$\begin{array}{c}\text { Degree of hydrolysis (\%) } \\
43.14 \pm 1.00^{\left.1 / \mathrm{c}^{2}\right)}\end{array}$} \\
\hline \multirow{6}{*}{$\begin{array}{c}\mathrm{pH} \\
\text { (at } 50^{\circ} \mathrm{C}, 10 \text { unit) }\end{array}$} & 4 & \\
\hline & 5 & $57.26 \pm 0.53^{\mathrm{b}}$ \\
\hline & 6 & $58.42 \pm 0.52^{\mathrm{b}}$ \\
\hline & 7 & $70.50 \pm 0.27^{\mathrm{a}}$ \\
\hline & 8 & $40.80 \pm 0.41^{\mathrm{d}}$ \\
\hline & 9 & $28.29 \pm 1.09^{e}$ \\
\hline \multirow{5}{*}{$\begin{array}{l}\text { Temperature }\left({ }^{\circ} \mathrm{C}\right) \\
\text { (at } \mathrm{pH} 7,10 \text { unit) }\end{array}$} & 30 & $59.11 \pm 0.31^{\mathrm{c}}$ \\
\hline & 40 & $63.63 \pm 0.54^{b}$ \\
\hline & 50 & $69.31 \pm 0.11^{\mathrm{a}}$ \\
\hline & 60 & $62.63 \pm 1.59^{\mathrm{c}}$ \\
\hline & 70 & $61.66 \pm 1.60^{\mathrm{b}}$ \\
\hline \multirow{5}{*}{$\begin{array}{l}\text { Enzyme concentration (unit) } \\
\qquad\left(\text { at } \mathrm{pH}, 50^{\circ} \mathrm{C} \text { ) }\right.\end{array}$} & 5 & $44.78 \pm 0.31^{\mathrm{e}}$ \\
\hline & 10 & $67.68 \pm 0.33^{\mathrm{a}}$ \\
\hline & 15 & $66.48 \pm 0.38^{b}$ \\
\hline & 20 & $64.60 \pm 0.06^{c}$ \\
\hline & 25 & $62.51 \pm 0.12^{\mathrm{d}}$ \\
\hline
\end{tabular}

${ }^{1)}$ Mean \pm SD (n=3).

${ }^{2)}$ Values with different letters in the same column are significantly different at $\mathrm{p}<0.05$.

다. 이상의 결과에 따라 flavourzyme를 이용한 들깨박단백 질 가수분해물 생산을 위한 최적 분해 조건은 $\mathrm{pH} 7.0,50^{\circ} \mathrm{C}$, 효소농도 10 unit, 가수분해시간은 4시간으로 설정하였으 며, 이 때의 가수분해도는 $69.16 \%$ 였다. 본 연구결과에서 얻은 들깨박단백질 가수분해 최적조건은 Table 1에서 제시 된 flavourzyme의 최적 $\mathrm{pH}$ 및 온도와 일치함을 알 수 있었으 며, 최적조건 하에서 효소분해 반응속도가 증가함에 따라 가수분해도가 높아진 것으로 판단된다.

\section{분획물의 수율}

가수분해도가 가장 높은 flavourzyme 가수분해물을 한외 여과장치를 이용하여 분자량 $>10 \mathrm{kDa}, 5-10 \mathrm{kDa}, 3-5 \mathrm{kDa}$, $1-3 \mathrm{kDa},<1 \mathrm{kDa}$ 으로 분획한 후 동결건조 하여 측정한 수율 을 Table 3 에 나타내었다. 가수분해물 분획물 5 가지 중에서 $1 \mathrm{kDa}$ 이하의 분획이 $45.65 \%$ 로 유의적으로 가장 높은 수율 을 보였다 $(\mathrm{p}<0.05)$. 이는 효소 작용으로 인해 고분자의 단백 질이 수용성의 저분자 펩타이드로 가수분해되어 수율이 높아진 것으로 판단된다. 또한, $>10 \mathrm{kDa}$ 분획과 $5-10 \mathrm{kDa}$ 분획은 각각 $16.37 \%$ 와 $16.45 \%$ 로 비슷한 수율을 보였으며, $3-5 \mathrm{kDa}$ 분획과 $1-3 \mathrm{kDa}$ 분획은 각각 $10.67 \%, 10.86 \%$ 으로 낮은 수율을 나타내었다. You 등(25)의 연구에서 담수어류 인 미꾸라지 단백질 가수분해물의 분자량별 수율을 측정한 결과, $1 \mathrm{kDa}$ 이하 분획의 수율이 $40.23 \%$ 으로 가장 높았다고 보고하여 본 연구 결과와 유사하였다. 그러나 Yang과 $\operatorname{Hong}(26)$ 의 연구에서는 $10 \mathrm{kDa}$ 이상의 수율이 가장 높은
것으로 나타나 본 연구 결과와 상이하였는데, 이는 사용된 기질, 효소, 반응시간 및 효소농도의 차이로 판단된다.

Table 3. Yield of peptide fractions obtained by ultrafiltration system from perilla seed meal protein hydrolysates

\begin{tabular}{cc}
\hline Fraction & Yield (\%) \\
\hline$>10 \mathrm{kDa}$ & $16.37 \pm 0.39^{1 / \mathrm{b} 2)}$ \\
$5-10 \mathrm{kDa}$ & $16.45 \pm 1.00^{\mathrm{b}}$ \\
$3-5 \mathrm{kDa}$ & $10.67 \pm 3.21^{\mathrm{c}}$ \\
$1-3 \mathrm{kDa}$ & $10.86 \pm 2.48^{\mathrm{c}}$ \\
$<1 \mathrm{kDa}$ & $45.65 \pm 0.63^{\mathrm{a}}$ \\
\hline
\end{tabular}

${ }^{1)}$ Mean \pm SD (n=3).

${ }^{2}$ Values with different letters in the same column are significantly different at $\mathrm{p}<0.05$

\section{항산화 활성}

항산화 반응은 항산화 물질이 유리 라디칼과 수산기 $(-\mathrm{OH})$ 가 결합하여 라디칼 생성 및 반응을 종결시켜주는 역할로 생체막의 활성산소 및 지질 과산화 라디칼에 의한 지질과산화 반응의 연쇄반응을 정지시킨다. 1,1-Diphenyl2-picryl hydrazyl(DPPH) 라디칼은 짙은 자색의 안정한 라디 칼로 항산화물질과 반응하여 탈색되어 노란색을 띄게 된 다. 이러한 원리를 이용하여 항산화 물질의 수소공여능을 측정하였다(27). 들깨박단백질의 효소가수분해물 및 한외 여과공정을 통해 얻은 분획물의 DPPH 라디칼 소거능을 측정하였다. 그 결과는 Fig. $2 \mathrm{~A}$ 에서 보는 바와 같이 효소가 수분해물의 $\mathrm{IC}_{50}$ 값이 $0.58 \mathrm{mg} / \mathrm{mL}$ 로 유의적으로 가장 낮아 높은 DPPH 라디칼 소거능을 나타내었다. 다음으로 $10 \mathrm{kDa}$ 이상의 분획이 $0.67 \mathrm{mg} / \mathrm{mL}, 3-5 \mathrm{kDa}$ 분획이 $0.79 \mathrm{mg} / \mathrm{mL}$ 의 $\mathrm{IC}_{50}$ 값을 나타내었다. $1 \mathrm{kDa}$ 이하의 분획은 $2.11 \mathrm{mg} / \mathrm{mL}$ 로 유의적으로 가장 높은 $\mathrm{IC}_{50}$ 값을 $\mathrm{DPPH}$ 라디칼 소거능이 가장 낮음을 알 수 있었다. 이러한 결과는 Bamdad와 Chen(28)이 보리단백질 효소가수분해의 라디칼 소거능은 $10 \mathrm{kDa}$ 이상에서 가장 높은 활성을 보였다고 보고한 연구 결과와 유사하였다. 또한 양송이버섯 단백질 가수분해물로 부터 한외여과에 의해 분획된 펩타이드의 $\mathrm{DPPH}$ 라디칼 소거능을 측정한 결과, $<1 \mathrm{kDa}$ 과 $3-5 \mathrm{kDa}$ 펩타이드 분획이 단백질 가수분해물에 비해 낮은 소거능을 보였으며, acalase 와 flavourzyme을 이용하여 얻은 가수분해물의 5-10 kDa 분획물이 가장 높은 라디칼 소거능을 나타낸 연구 결과(29) 와 유사하였다. 이러한 결과는 효소가수분해물과 5-10 kDa 의 한외여과 분획물은 전자공여능을 가지고 있는 펩타이드 또는 아미노산을 함유하고 있어 $\mathrm{DPPH}$ 라디칼을 안정화시 키고 라디칼 연쇄반응을 차단할 수 있기 때문으로 판단된 다. 반면, 닭뼈에서 용출된 펩타이드를 한외여과를 통해 얻은 $3 \mathrm{kDa}$ 이하 분획이 $3-10 \mathrm{kDa}$ 분획에 비해 높은 $\mathrm{DPPH}$ 라디칼 소거능을 보여(30) 본 연구 결과와 차이가 있었다. Collupulin $\mathrm{MG}$ 를 이용하여 도루묵으로부터 얻은 효소가수 
분해물과 한외여과 펩타이드의 DPPH 라디칼 소거능을 측 정한 결과 $(18), 1.0 \mathrm{mg} / \mathrm{mL}$ 농도에서 $8-24 \%$ 의 라디칼 소거 능을 가지고 있어 본 연구에서 얻은 들깨박단백질의 DPPH 라디칼 소거능이 우수함을 알 수 있었다. 또한 $3 \mathrm{kDa}$ 이하의 펩타이드 분획의 라디칼 소거능이 가장 우수하였으며, 그 다음 $10 \mathrm{kDa}$ 이상의 펩타이드 분획이 두 번째로 높은 라디 칼 소거능을 보여(18), 본 연구 결과와 다소 차이를 보였다. 이러한 차이는 DPPH 라디칼 소거능은 효소의 특이성, 펩타 이드의 분자량, 아미노산의 종류 및 배열에 따라 그 활성에 차이를 보이기 때문으로 판단된다(3).

들깨박단백질의 효소가수분해물 및 이들 분획물의 환원 력을 측정한 결과(Fig. 2B), 3-5 kDa 분획이 $136.42 \mu \mathrm{g} / \mathrm{mL}$ 의 $\mathrm{IC}_{50}$ 값으로 유의적으로 가장 높은 환원력을 나타내었으며, $10 \mathrm{kDa}$ 이상 분획이 $150.59 \mathrm{\mu g} / \mathrm{mL}$ 의 $\mathrm{IC}_{50}$ 값으로 두 번째로 높은 환원력을 나타내었다. 반면, $1 \mathrm{kDa}$ 이하의 분획이 $564.16 \mu \mathrm{g} / \mathrm{mL}$ 로 가장 높은 $\mathrm{IC}_{50}$ 값을 나타내어 환원력이 가장 낮음을 알 수 있었다. 닭뼈 추출물을 한외여과하여 얻은 펩타이드 분획의 환원력을 측정한 결과, $2 \mathrm{mg} / \mathrm{mL}$ 농도 에서 0.08-0.18의 환원력을 보였으며, 저분자 펩타이드 분 획(3 kDa 이하)이 고분자 펩타이드 분획 $(3-10 \mathrm{kDa})$ 에 비해 높은 환원력을 보여(30) 본 연구결과와 다소 차이를 보였다. 양송이버섯 단백질을 flavourzyme과 alcalase를 비롯한 다 양한 단백질가수분해효소를 이용하여 가수분해 후 한외여 과를 통해 얻은 펩타이드의 환원력을 측정한 결과, $1 \mathrm{mg} / \mathrm{mL}$ 농도에서 약 0.1-0.2의 환원력을 나타내어 본 연구에서 얻은 단백질 분획물의 환원력이 매우 높음을 알 수 있었다(29). 또한 flavourzyme을 이용하여 얻은 가수분해물 및 한외여 과 분획물의 환원력은 $1 \mathrm{kDa}$ 이하가 가장 높은 반면, 10 $\mathrm{kDa}$ 이상 분획물의 환원력이 가장 낮게 나타나(29) 본 연구 결과와 차이가 있었다.

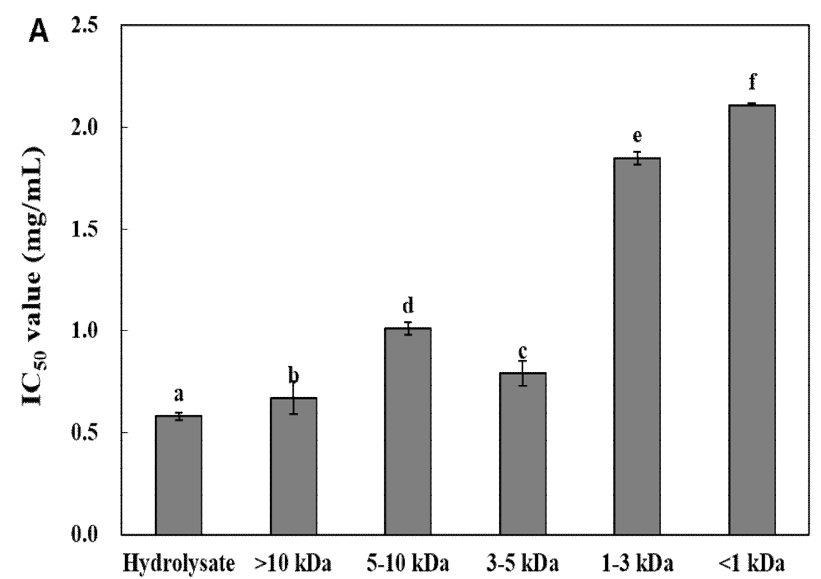

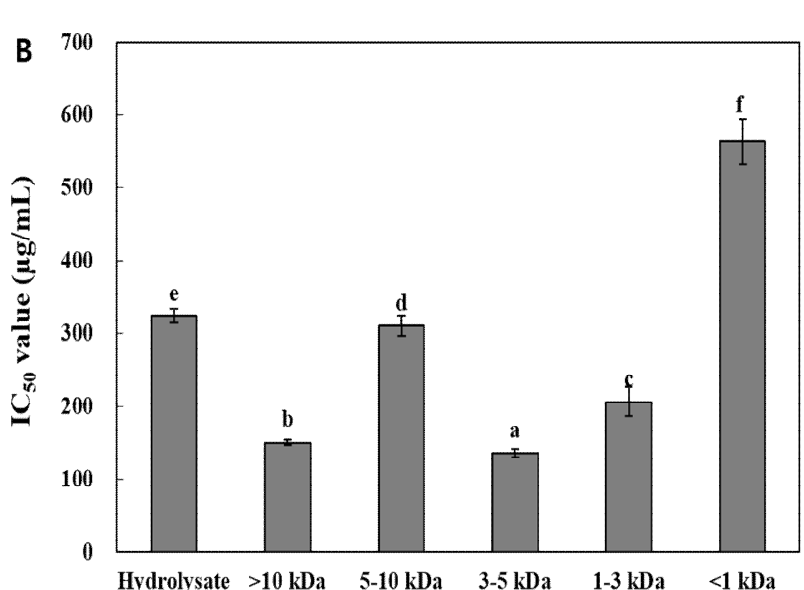

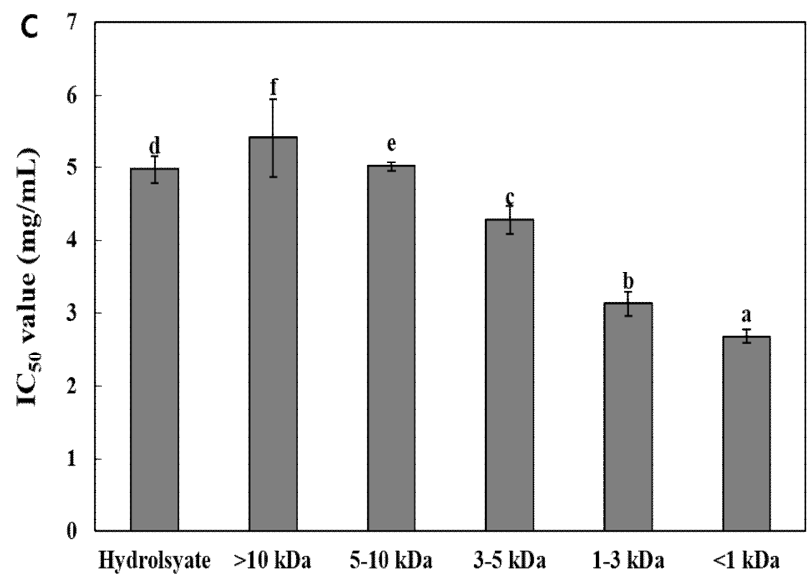

Fig. 2. Antioxidant activity of the enzymatic hydrolysate and peptides obtained from perilla seed meal protein. A, DPPH radical scavenging activity; B, Reducing power; C, SOD-like activity.

The bar represents the mean and standard deviation $(\mathrm{n}=3)$. Values with different letters are significantly different at $p<0.05$

세포의 호흡작용에 의해 생성되는 활성산소종은 세포막 에 작용하여 세포 손상, DNA 및 단백질에 영향을 주어 노화를 촉진시킨다. Superoxide는 산소가 전자 하나를 받아 환원된 형태로 체내 산화적 손상을 야기할 수 있으며, SOD 는 $2 \mathrm{O}_{2}{ }^{-}+2 \mathrm{H}^{+} \rightarrow \mathrm{H}_{2} \mathrm{O}_{2}+\mathrm{O}_{2}$ 와 같은 반응으로 활성산소로부터 세포를 보호한다. $\mathrm{SOD}$ 유사물질이란 $\mathrm{SOD}$ 와 같이 superoxide를 정상의 산소로 전환시킬 수는 없으나 superoxide의 반응성을 억제하여 생체를 산화적 손상으로 부터 보호할 수 있는 저분자 물질을 의미한다(31). 따라서 SOD 유사활성은 중성이나 알칼리 조건 하에서 superoxide 에 의해 pyrogallol이 자동산화 되면서 갈색물질을 생성하 는 원리를 이용하여 자동산화를 억제하는 정도로 활성을 측정하였다(32). 들깨박단백질의 효소가수분해물 및 이들 분획물의 $\mathrm{SOD}$ 유사활성을 측정한 결과는 Fig. $2 \mathrm{C}$ 에 나타내 었으며, $1 \mathrm{kDa}$ 이하 분획물이 가장 낮은 $\mathrm{IC}_{50}$ 값(2.68 $\mathrm{mg} / \mathrm{mL}$ )을 나타내었다. $1-3 \mathrm{kDa}, 3-5 \mathrm{kDa}, 5-10 \mathrm{kDa}$ 및 10 이상 분획의 $\mathrm{IC}_{50}$ 값은 각각 $3.13,4.28,5.02$ 및 $5.41 \mathrm{mg} / \mathrm{mL}$ 로 측정되어 분자량이 작을수록 $\mathrm{SOD}$ 유사활성은 커지는 것으 로 나타났다. 또한 단백질 효소가수분해물의 $\mathrm{IC}_{50}$ 값은 4.98 
$\mathrm{mg} / \mathrm{mL}$ 로 분획 중 중간 정도의 활성을 보였다. 이상의 결과 들깨박단백질 효소가수분해물 중 저분자 분획물이 높은 SOD 유사활성을 가져 섭취 시 인체 내 superoxide를 제거하 고 산화적 노화를 억제하는 데 도움을 줄 수 있을 것으로 판단된다.

\section{요 약}

본 연구에서는 단백질 함량이 높은 들깨박을 기능성 식 품소재로서의 활용가능성을 확인하기 위하여 단백질분해 효소 및 한외여과를 이용하여 가수분해물과 펩타이드 분획 을 제조하고 이들의 항산화 활성을 측정하였다. 먼저 들깨 박단백질의 가수분해물 생산을 위한 최적 효소를 선정하기 위해 단백질분해효소 7종을 이용하여 효소 반응 후 가수분 해도를 측정한 결과, flavourzyme이 가장 높은 가수분해율 을 나타내었다. Flavourzyme에 의한 들깨박단백질 가수분 해물을 얻기 위한 최적 조건은 $\mathrm{pH} 7.0,50^{\circ} \mathrm{C}$, 효소농도 10 unit, 가수분해시간은 4시간으로 결정되었다. 들깨박단백 질 가수분해물을 한외여과 후 얻은 각 분획의 수율은 1 $\mathrm{kDa}$ 이하가 $45.65 \%$ 로 유의적으로 가장 높았으며, 그 다음 으로 5-10 kDa(16.45\%), $10 \mathrm{kDa}$ 이상(16.37\%), 1-3 kDa(10.86\%), 3-5 $\mathrm{kDa}(10.67 \%)$ 순으로 높았다. $\mathrm{DPPH}$ 라디칼 소거능은 효소가수분해물이, 환원력은 3-5 $\mathrm{kDa}$ 분획물이, superoxide dismutase 유사활성은 $1 \mathrm{kDa}$ 이하의 분획물이 가장 높은 활성을 나타내었다. 따라서 들깨박단백질로부터 생산된 가 수분해물 및 펩타이드 분획은 각기 다른 항산화 활성 특성 을 보여 기능성 식품 소재의 목적에 맞게 선택하여 활용할 수 있을 것으로 판단된다. 또한 향후 식품학적 기능성 평가 가 이루어진다면 식품산업에서 다양한 식품재료로의 활용 성이 확대될 수 있을 것으로 판단된다.

\section{References}

1. Korhonen H, Pihlanto A (2006) Bioactive peptides: production and functionality. Int Dairy J, 16, 945-960

2. Kitts DD, Weiler K (2003) Bioactive proteins and peptides from food sources. Applications of bioprocesses used in isolation and recovery. Curr Pharm Des, 9, 1309-1323

3. Jang HR, Liceaga AM, Yoon KY (2016) Purification, characterisation and stability of an antioxidant peptide derived from sandfish (Arctoscopus japonicus) protein hydrolysates. J Funct Foods, 20, 433-442

4. Jang HR, Liceaga AM, Yoon KY (2017) Isolation and characteristics of anti-inflammatory peptides from enzymatic hydrolysates of sandfish (Arctoscopus japonicus) protein. J Aquat Food Prod Technol, 26, 234-244

5. Liu M, Wang Y, Liu Y, Ruan R (2016) Bioactive peptides derived from traditional Chinese medicine and traditional Chinese food: a review. Food Res Int, 89, 63-73

6. Guo YX, Pan DD, Tanokura M (2009) Optimisation of hydrolysis conditions for the production of the angiotensin-I converting enzyme (ACE) inhibitory peptides from whey protein using response surface methodology. Food Chem, 114, 328-333

7. Benitez R, Ibarz A, Pagan J (2008) Protein hydrolysates: processes and applications. Acta Bioquim Clin Latinoam, 42, 227-236

8. Jang HR, Yoon KY (2018) Optimal conditions of enzymatic hydrolysis for producing anti-inflammatory peptides from sandfish (Arctoscopus japonicus) hydrolysate. Korean J Food Sci Technol, 50, 203-208

9. Gang HJ, Kim JS (1998) Bioactive of perilla. Food Industry and Nutrition, 3, 65-72

10. Ministry of Health \& Welfare (2010) Korea national health and nutrition examination survey (KNHANES) V-1. Korea Health Statistics, Seoul, Korea, p 345-348

11. Lee KY (1993) Antioxidant effects of phenolic compounds isolated from defatted perilla seed flour. Korean J Food Sci Technol, 25, 9-14

12. Mohammad A (2011) Health effects of omega-3,6,9 fatty acids: Perilla frutescens is a good example of plant oils. Orient Pharm Exp Med, 11, 51-59

13. Park DS, Lee KI, Park KY (2001) Quantitative analysis of dietary fibers from Perilla frutescens seeds and antimutagenic effect of its extracts. J Korean Soc Food Sci Nutr, 30, 900-905

14. Son JY, Jang SH (2013) Physiological activities of enzyme hydrolysates in ethanol extracts from sesame, black sesame and perilla cake. Korean J Food Cookery Sci, 29, 407-416

15. Anson ML (1939) The estimation of pepsin, trypsin, papain, and cathepsin with hemoglobin. J Gen Physiol, 22, 79-88

16. Xie Z, Huang J, Xu X, Jin Z (2008) Antioxidant activity of peptides isolated from Alfalfa leaf protein hydrolysate. Food Chem, 111, 370-376

17. Smith P, Krohn RI, Hermanson G, Mallia A, Gartner F, Provenzano M, Fujimoto E, Goeke N, Olson B, Klenk D (1985) Measurement of protein using bicinchoninic acid. Anal Biochem, 150, 76-85 
18. Jang HR, Shin SR, Yoon KY (2017) Isolation of antioxidant peptide from sandfish (Arctoscopus japonicus) roe hydrolysate. Koeran J Food Preserv, 24, 542-549

19. Mau JL, Lin HC, Song SF (2002) Antioxidant properties of several specialty mushrooms. Food Res Int, 35, 519-526

20. Bradford MM (1976) A rapid and sensitive method for the quantitation of microgram quantities of protein utilizing the principle of protein-dye binding. Anal Biochem, 72, 248-254

21. Yoon BY, Choi BD, Choi YJ (2010) Extraction of glycosaminoglycan from Sea Hare, Aplysia kurodai, and its functional properties: optimum extraction of polysaccharide and purification of glycosaminoglycan. J Korean Soc Food Sci Nutr, 39, 1640-1646

22. Kim MR (2010) Bitterness and solubility of soy protein, casein, gluten, and gelatin hydrolysates treated with various enzymes. J Korean Soc Food Sci Nutr, 39, 587-594

23. Baek JH, Jeong EJ, Jeon SY, Cha YJ (2011) Optimal conditions for enzymatic hydrolysate of snow crab Chionoecetes japonicus cooker effluent using response surface methodology. Korean J Fish Aquat Sci, 44, 99-103

24. Jang JT, Seo WH, Baek HH (2009) Enzymatic hydrolysis optimization of a snow crab processing by-product. Korean J Food Sci Technol, 41, 622-627

25. You L, Zhao M, Regenstein JM, Ren J (2010) Purification and identification of antioxidative peptides from loach (Misgurnus anguillicaudatus) protein hydrolysate by consecutive chromatography and electrospray ionizationmass spectrometry. Food Res Int, 43, 1167-1173

26. Yang SJ, Hong JH (2014) Physicochemical properties and biological activities of collagens with different molecular weights from alaska pollack (Theragra chalcogramma) skin. J Korean Soc Food Sci Nutr, 43, 1535-1542

27. Bondent V, Brand-Williams W, Berset C (1997) Kinetics and mechanism of antioxidant activity using the DPPH free radical methods. LWT-Food Sci Technol, 30, 609-615

28. Bamdad F, Chen L (2013) Antioxidant capacities of fractionated barley hordein hydrolysates in relation to peptide structures. Mol Nutr Food Res, 57, 493-503
29. Kimatu BM, Zhao L, Biao Y, Ma G, Yang W, Pei F, $\mathrm{Hu} \mathrm{Q}$ (2017) Antioxidant potential of edible mushroom (Agaricus bisporus) protein hydrolysates and their ultrafiltration fractions. Food Chem, 230, 58-67

30. Nie X, Xu D, Zhao L, Meng X (2017) Antioxidant activities of chicken bone peptide fractions and their Maillard reaction products: Effects of different molecular weight distributions. Int J Food Prop, 20, S457-S466

31. Han DS, Kim SJ (1994) SOD-like compounds and development of functional food. Bull Food Technol, 7, 41-49

32. Moon YG, Choi KS, Lee KJ, Kim KY, Heo MS (2006) Screening of antioxidative and antibacterial activity from hot water extracts of indigenous plants, Jeju-Island. Korean J Biotechnol Bioeng, 21, 164-169 